\title{
Invasive biota in the deep-sea Mediterranean: an emerging issue in marine conservation and management
}

\author{
B. S. Galil · R. Danovaro $\cdot$ S. B. S. Rothman $\cdot$ R. Gevili $\cdot$ M. Goren
}

Received: 18 April 2018/Accepted: 19 August 2018/Published online: 27 August 2018

(C) The Author(s) 2018

\begin{abstract}
Although the ecological importance and impact of non-indigenous species is increasingly recognised and documented in shallow water ecosystems, their presence beyond the shelf has scarcely been documented. A survey of the upper slope biota of the Mediterranean coast of Israel revealed the presence at 200-m depth of individuals of three Erythraean species, the crocodile toothfish Champsodon
\end{abstract}

Electronic supplementary material The online version of this article (https://doi.org/10.1007/s10530-018-1826-9) contains supplementary material, which is available to authorized users.

B. S. Galil $(\bowtie)$

The Steinhardt Museum of Natural History, Tel Aviv University, Tel Aviv 69978, Israel

e-mail: galil@post.tau.ac.il

\section{R. Danovaro}

Polytechnic University of Marche, 60121 Ancona, Italy

R. Danovaro

Stazione Zoologica Anton Dohrn, 80121 Naples, Italy

S. B. S. Rothman

School of Zoology, Tel Aviv University, Tel Aviv 69978, Israel

R. Gevili

Ashdod, Israel

M. Goren

The Steinhardt Museum of Natural History, and School of Zoology, Tel Aviv University, Tel Aviv 69978, Israel nudivittis, Golani's round herring Etrumeus golanii, and the burrowing goby, Trypauchen vagina. In the past decade several Erythraean species, some newly arrived, some well-established, have been collected on the Levantine lower shelf and upper slope. The species invasion revealed that thermal niche estimations based on the species' native environment may have underestimated their ability to tolerate lower temperatures. The results reported here suggest that the wide thermal tolerance of some Erythraean species may facilitate their bathymetric and geographic expansion. Their spread to the depths where the unique, diverse and fragile mesophotic 'animal forests' occur, bodes ill to these beleaguered communities.

Keywords Invasive alien species - Deep-sea · Mediterranean $\cdot$ Monitoring $\cdot$ Conservation

\section{Introduction}

In the coastal ecosystems of the Mediterranean Sea, bioinvasions present threats to the local biodiversity comparable to those exerted by climate change, pollution and fisheries (Micheli et al. 2013; EEA 2015; Galil et al. 2018). The number of non-indigenous species (NIS) more than doubled in the past 30 years, and is substantially greater in the Levant than in other basins in the Mediterranean due to the propagule pressure exerted by the Suez Canal, which 
serves as the major pathway of introduction. NIS along the Mediterranean coast of Israel, mainly fish, decapod crustaceans and molluscs, have been recorded since the early 20C, and more consistently since the midcentury. The introduction through the Suez Canal, the Erythraean invasion, is causing a dramatic restructuring of biotic communities, altering ecosystem functions and affecting the availability of biological resources and ecosystem services. (Galil 2007a, b, 2008, 2017; Galil et al. 2018; Goren et al. 2016).

Since the Suez Canal is shallow, it has been assumed that the populations of the NIS introduced through the canal into the Mediterranean will be restricted to the upper shelf (https://www.suezcanal. gov.eg/English/About/SuezCanal/Pages/CanalCharac teristics.aspx). Indeed, until the 1970s Erythraean biota entering in the Mediterranean was typically confined to habitats shallower than $50 \mathrm{~m}$ (Galil and Lewinsohn 1981; Tom and Galil 1991). A survey of bottom communities off Ashdod, at the southern Mediterranean coast of Israel, carried out in 2010-2012 included 16 trawl hauls each along the 100 and $120 \mathrm{~m}$ isobaths, as well as 4 hauls at $250 \mathrm{~m}$. The resulting findings have upended this paradigm as Erythraean biota was collected on the deeper portions of the shelf (Table 1). A survey along the $200 \mathrm{~m}$ isobath off Ashdod, conducted between October and
December 2017, collected 8 specimens of the crocodile toothfish Champsodon nudivittis (Ogilby, 1895), and a single specimen each of Etrumeus golanii Di Battista et al. 2012, and the burrowing goby Trypauchen vagina (Bloch and Schneider, 1801). Champsodon nudivittis occurs in the Indo-Pacific Ocean over a wide bathymetric range (Nemeth 1994). As its common name-crocodile toothfish-implies, it is carnivorous predator, feeding on shrimp and fish. It was collected at the Dahlak Archipelago, southern Red Sea, at depth of $36 \mathrm{~m}$ (Goren et al. 2011), and at the north-eastern Arabian Sea at depths of 282-393 m (Goren et al. 2014), where the water temperature is 13-14 ${ }^{\circ} \mathrm{C}$ (Shankar et al. 2005). Recently reported from the eastern Mediterranean, it was first recorded in Iskenderun Bay, Turkey, in 2008, at $50 \mathrm{~m}$ depth (Çiçek and Bilecenoglu 2009), and subsequently in deeper waters (Table 2, Fig. 1). Etrumeus golanii was recorded from the upper shelf in the northern Red Sea (Di Battista et al. 2012), and is noted for its protracted spawning season, and high absolute fecundity (3953-12698) (Osman et al. 2011). It was first recorded in the Mediterranean Sea from Israel in 1961, and subsequently spread across the sea to Algeria (Di Battista et al. 2012, Stamouli et al. 2017) The sea surface temperature in the northern Gulf of Aqaba ranges between 21.2 and $27.8{ }^{\circ} \mathrm{C}$ (Shaked and Genin 2017) but only $14.5-24.5^{\circ} \mathrm{C}$ off Algeria (Manca et al.
Table 1 Erythraean fish recorded in 2010-2011 at depths of 100 and $120 \mathrm{~m}$ off Ashdod, Mediterranean coast of Israel

\begin{tabular}{lllr}
\hline Species & First record in Israel & $100 \mathrm{~m}$ & $120 \mathrm{~m}$ \\
& & N specimens & N specimens \\
\hline Bregmaceros nectabanus & 2004 & 2 & 1 \\
Champsodon nudivittis & 2011 & 2 & 1 \\
Cynoglossus sinusarabici & 1953 & 1 & 1 \\
Equulites klunzingeri & 1934 & 805 & 271 \\
Etrumeus golanii & 1961 & 8 & 10 \\
Jaydia queketti & 2007 & 6 & 5 \\
Jaydia smithi & 2007 & 10 & 1758 \\
Nemipterus randalli & 2005 & 2268 & 3 \\
Ostorhinchus fasciatus & 2008 & 36 & 1 \\
Oxyurichthys petersi & 1982 & - & 1 \\
Parexocoetus mento & 1935 & - & 293 \\
Sargocentron rubrum & 1947 & 10 & 3 \\
Saurida lessepsianus & 1952 & 491 & 3 \\
Sphyraena pinguis & 1931 & 2 & 660 \\
Trypauchen vagina & 2009 & 6 & 917 \\
Upeneus molluccensis & 1947 & & \\
\hline
\end{tabular}


Table 2 Locations of records of Etrumeus golanii Di Battista et al. 2012, Champsodon nudivittis (Ogilby, 1895), and Trypauchen vagina (Bloch and Schneider, 1801) on the shelf

\begin{tabular}{|c|c|c|c|c|c|}
\hline Species & Locality & Depth, m & $\begin{array}{l}\text { Marked } \\
\text { in map } \\
\text { as }\end{array}$ & $\begin{array}{l}\text { Collection } \\
\text { year }\end{array}$ & References \\
\hline $\begin{array}{l}\text { Etrumeus } \\
\text { golanii }\end{array}$ & $\begin{array}{l}\text { Algeria, } \\
\text { Cherchell }\end{array}$ & 30 & A 9 & 2017 & Stamouli et al. (2017) \\
\hline $\begin{array}{l}\text { Etrumeus } \\
\text { golanii }\end{array}$ & $\begin{array}{l}\text { Cyprus, } \\
\text { Larnaca }\end{array}$ & unavailable & A 2 & 2012 & SMNH-P 15068 \\
\hline $\begin{array}{c}\text { Etrumeus } \\
\text { golanii }\end{array}$ & $\begin{array}{l}\text { Cyprus, } \\
\text { Limassol }\end{array}$ & 50 & A 2 & 1999 & Golani (2000) \\
\hline $\begin{array}{c}\text { Etrumeus } \\
\text { golanii }\end{array}$ & $\begin{array}{l}\text { Egypt, } \\
\text { Alexandria }\end{array}$ & $41-58$ & A 11 & 2007 & Akel (2009) \\
\hline $\begin{array}{c}\text { Etrumeus } \\
\text { golanii }\end{array}$ & Greece, Crete & $59-62$ & A 7 & 2005 & Kasapidis et al. (2007) \\
\hline $\begin{array}{l}\text { Etrumeus } \\
\text { golanii }\end{array}$ & $\begin{array}{l}\text { Greece, } \\
\text { Cyclades }\end{array}$ & 110 & A 6 & 2005 & Kallianiotis and Lekkas (2005) \\
\hline $\begin{array}{c}\text { Etrumeus } \\
\text { golanii }\end{array}$ & Greece, Rhodes & $30-50$ & A 5 & 2003-2004 & Corsini et al. (2005) \\
\hline $\begin{array}{l}\text { Etrumeus } \\
\text { golanii }\end{array}$ & $\begin{array}{l}\text { Israel, Ashdod- } \\
\text { Haifa }\end{array}$ & $11-100$ & A 1 & 2008-2014 & $\begin{array}{l}\text { SMNH-P 13575; 13576; 13961; 14152; 14244; } \\
\quad \text { 14248;14327; 14498;14680;14759;14852;15086; } \\
15230 ; 15480\end{array}$ \\
\hline $\begin{array}{c}\text { Etrumeus } \\
\text { golanii }\end{array}$ & $\begin{array}{l}\text { Italy, } \\
\text { Lampedusa }\end{array}$ & 65 & A 8 & 2005 & Falautano et al. (2006) \\
\hline $\begin{array}{l}\text { Etrumeus } \\
\text { golanii }\end{array}$ & $\begin{array}{l}\text { Tunisia, Zarzis, } \\
\text { Gulf of } \\
\text { Gabes }\end{array}$ & 30 & A 10 & 2014 & Boussellaa et al. (2016) \\
\hline $\begin{array}{l}\text { Etrumeus } \\
\text { golanii }\end{array}$ & $\begin{array}{l}\text { Turkey, Dikili } \\
\text { coast }\end{array}$ & $40-50$ & A 4 & 2009 & Yarmaz et al. (2010) \\
\hline $\begin{array}{l}\text { Etrumeus } \\
\text { golanii }\end{array}$ & $\begin{array}{l}\text { Turkey, Izmir } \\
\text { Bay }\end{array}$ & 63 & A 3 & 2015 & Akyol and Ulas (2016) \\
\hline $\begin{array}{l}\text { Champsodon } \\
\text { nudivittis }\end{array}$ & Greece, Rhodes & 150 & B 7 & 2012 & Kalogirou and Corsini-Foka (2012) \\
\hline $\begin{array}{l}\text { Champsodon } \\
\text { nudivittis }\end{array}$ & Israel, Ashdod & 100 & B 1 & 2011 & Goren et al. (2011) \\
\hline $\begin{array}{l}\text { Champsodon } \\
\text { nudivittis }\end{array}$ & Israel, Ashdod & $60-120$ & B 1 & 2012-2016 & $\begin{array}{l}\text { SMNH-P } 14329 ; 14520 ; 14587 ; 14593 ; 15492 ; 15493 ; \\
\quad 15494 ; 15495 ; 15496 ; 15845 ; 15896 ;\end{array}$ \\
\hline $\begin{array}{l}\text { Champsodon } \\
\text { nudivittis }\end{array}$ & $\begin{array}{l}\text { Turkey, } \\
\text { Antalya Bay }\end{array}$ & $140-150$ & B 3 & 2010 & Gökoğlu et al. (2011) \\
\hline $\begin{array}{l}\text { Champsodon } \\
\text { nudivittis }\end{array}$ & $\begin{array}{l}\text { Turkey, } \\
\text { Edremit Bay }\end{array}$ & 60 & B 6 & 2014 & Torcu Koç et al. (2015) \\
\hline $\begin{array}{l}\text { Champsodon } \\
\text { nudivittis }\end{array}$ & $\begin{array}{l}\text { Turkey, } \\
\text { Ekincik Bay }\end{array}$ & $55-72$ & B 5 & 2010-2011 & Filiz et al. (2014) \\
\hline $\begin{array}{l}\text { Champsodon } \\
\text { nudivittis }\end{array}$ & $\begin{array}{l}\text { Turkey, } \\
\text { Fethiye Bay }\end{array}$ & $120-190$ & B 4 & 2010-2011 & Filiz et al. (2014) \\
\hline $\begin{array}{l}\text { Champsodon } \\
\text { nudivittis }\end{array}$ & $\begin{array}{l}\text { Turkey, Finike } \\
\text { Bay }\end{array}$ & 180 & B 4 & 2011 & Erguden and Turan (2011) \\
\hline $\begin{array}{l}\text { Champsodon } \\
\text { nudivittis }\end{array}$ & $\begin{array}{l}\text { Turkey, } \\
\text { Iskenderun } \\
\text { Bay }\end{array}$ & 50 & B 2 & 2008 & Çiçek and Bilecenoglu (2009) \\
\hline $\begin{array}{l}\text { Trypauchen } \\
\text { vagina }\end{array}$ & $\begin{array}{l}\text { Israel, Atlit and } \\
\text { Hadera }\end{array}$ & 90 & C 1 & 2009 & Salameh et al. (2010) \\
\hline
\end{tabular}

and upper slope in the Mediterranean Sea-locality, depth (m), year of collection, and reference 
Table 2 continued

\begin{tabular}{llllll}
\hline Species & Locality & Depth, m & $\begin{array}{l}\text { Marked } \\
\text { in map } \\
\text { as }\end{array}$ & $\begin{array}{l}\text { Collection } \\
\text { year }\end{array}$ & References \\
\hline $\begin{array}{c}\text { Trypauchen } \\
\text { vagina }\end{array}$ & Israel, Ashdod & $60-120$ & C 1 & $2012-2016$ & SMNH-P 14566; 14567; 15871; 15897 \\
$\begin{array}{c}\text { Trypauchen } \\
\text { vagina }\end{array}$ & $\begin{array}{c}\text { Turkey, } \\
\text { Iskenderun } \\
\text { Bay }\end{array}$ & $20-27$ & C 2 & 2010 & Akamca et al. (2011) \\
$\begin{array}{c}\text { Trypauchen } \\
\text { vagina }\end{array}$ & $\begin{array}{c}\text { Turkey, Mersin } \\
\text { vag-30 }\end{array}$ & C 3 & 2012 & Siokou et al. (2013) \\
\hline
\end{tabular}

Each record marked with numeral as in Fig. 1

SMNH Steinhardt Museum of Natural History

Fig. 1 Occurrence of three Erythraean non-indigenous species in the Mediterranean Sea. a Etrumeus golanii Di Battista et al. 2012,

b Champsodon nudivittis (Ogilby, 1895),

c Trypauchen vagina (Bloch and Schneider, 1801).

Details presented in Table 2

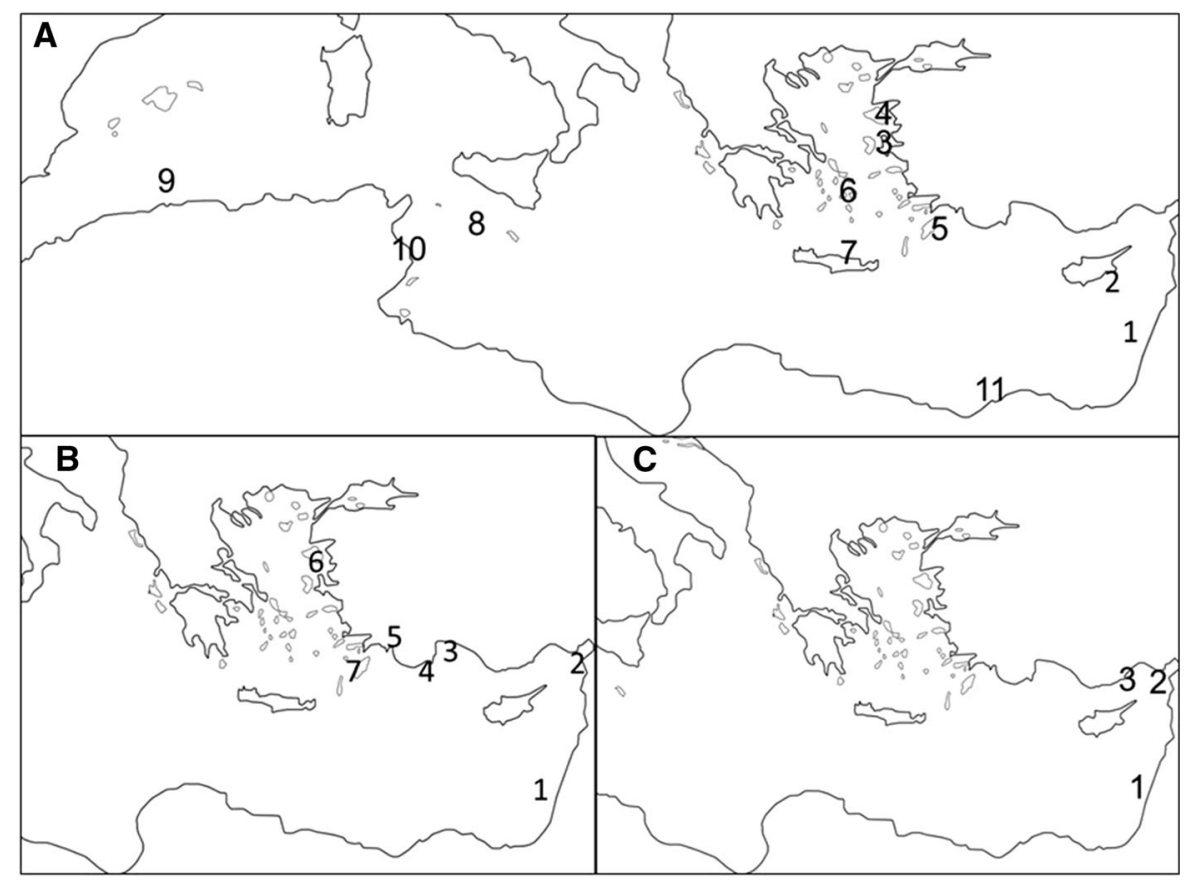

2004). (Table 2, Fig. 1). Trypauchen vagina occurs in the Indo-west Pacific Ocean in shallow estuarine and coastal areas (Murdy 2006). It too displays high batch fecundity (4000-12,750 eggs/female/spawning) (Dinh 2018). It was collected in muddy coastal waters in the Persian Gulf at depths of 10-20 m (Murdy 2006; Alavi-Yeganeh et al. 2015) where sea surface temperatures ranged between 20 and $32{ }^{\circ} \mathrm{C}$ (Al Azhar et al. 2016) as compared to $17.5-28.5^{\circ} \mathrm{C}$ in Iskenderun Bay, Turkey (Gucel and Sakalli 2018). Off the Israeli coast specimens were collected at greater depths (Table 2, Fig. 1).

\section{What may have caused thermophilic NIS, some newly arrived, some established for decades, to spread to the lower shelf and upper slope?}

The successive enlargements of the Suez Canal conducted from 1996 to 2015 have increased its depth from 
21 to $24 \mathrm{~m}$ and its cross sectional area from 3850 to $5200 \mathrm{~m}^{2}$ (https://www.suezcanal.gov.eg/English/ About/SuezCanal/Pages/CanalCharacteristics.aspx). The increased volume of water in conjunction with higher through-current velocities have likely increased propagule pressure-increasing the delivery of Erythraean species, including epipelagic larvae/juveniles of deeper living fish. Both the Red Sea and the Mediterranean Sea are characterized by high deepwater Temperatures. Sea water temperatures measured on the southern Israeli upper shelf from 2014 to 2017 span a range from $18{ }^{\circ} \mathrm{C}$ in February to $31^{\circ} \mathrm{C}$ in August. Vertical temperature profiles show a typical seasonal pattern with winter thermal mixing creating fairly constant high temperature, $17.5{ }^{\circ} \mathrm{C}$, as deep as $260 \mathrm{~m}$ in 2015, $150 \mathrm{~m}$ in 2016, and nearly $200 \mathrm{~m}$ in 2017 (Herut and Rahav 2017). Both Levantine surface (0-50 m) and intermediate (150-350 m) water masses (LSW, LIW) along the Mediterranean coast of Israel have displayed long-term increase in temperature of $+0.12 \pm 0.07$ and $+0.03 \pm 0.02{ }^{\circ} \mathrm{C}_{\text {year }}{ }^{-1}$, , respectively (Ozer et al. 2017). As cold temperatures are considered to limit the geographic distribution of marine thermophilic poikilotherm organisms (Hutchins 1947), a wider thermal niche confers advantages to NIS, as they are likelier to colonize, establish viable populations, and spread in novel habitats. The potential distribution of NIS is commonly predicted using the environmental niche model, which considers a known distribution of a species and then defines a potential and realized niche of a species correlating the available information with the environmental variables of a wider area (Monahan 2009). The invasion of Erythraean species of the Levantine basin, and particularly their recently observed intrusion into the lower continental shelf and upper slope revealed that thermal niche estimations assuming niche conservatism and based on the species' native environment may underestimate their capacity to tolerate lower temperatures. It seems that the climatic niche of some Erythraean species is wider than accounted for, or has altered during the invasion, and is likely to facilitate bathymetric range expansion, as well as higher invasion risk into a wider geographic range.

\section{Why does it matter?}

Antipatharians, ceriantharians, zoantharians, gorgonians and pennatulaceans have been documented on the shelf and upper slope of the Aegean and Levant seas (mainly < $250 \mathrm{~m}$ depth) (Zibrowius 1979a, b; Chintiroglou et al. 1989; Vafidis et al. 1994, 1997; Vafidis and Koukouras 1998 [2002]; Vafidis 2009; Abdelsalam 2014). Recently, a dense population of Dendrophyllia ramea (Linnaeus, 1758) has been described in the Levant from eastern Cyprus and Lebanon. The Cypriot population of $D$. ramea was recorded on soft substrate at depths between 125 and $155 \mathrm{~m}$, whereas the deepest record has been documented in Lebanese waters, at 172 m depth (Jimenez et al. 2016; Orejas et al. 2017; OCEANA, 2016). These large arborescent anthozoans form patchy 'meadows' which attract highly diverse mesophotic assemblages (Cerrano et al. 2010; Zeppilli et al. 2016). These mesophotic assemblages are vulnerable to injury from bottom contact fisheries (Pusceddu et al. 2014), together with pollution, offshore extraction and infrastructure, and climate change (Aguilar et al. 2017; Danovaro et al. 2017b). Yet, so far no mention has been made on the direct impact of bioinvasions, which has been considered a priority issue in the coastal Mediterranean environment (Coll et al. 2010). The occurrence of carnivorous and highly fecund NIS at these depths does not bode well. Examination of the ecological impacts of some conspicuous NIS in the Mediterranean Sea underscores their role, among multiple anthropogenic stressors, in altering the littoral and sublittoral communities. Local population losses and niche contraction of native species augur reduction of genetic diversity, loss of functions, processes, and habitat structure, and increase the risk of local extirpations (Galil 2007a). Should a similar process occur in deeper waters, the indigenous biodiversity and sustainability of the unique mesophotic assemblages may be put under severe strain.

\section{The first step for management of deep-living NIS}

The first step in addressing NIS in deep-sea habitats is to study their presence, distribution, ecology, pathway, and to assess the threats they present, and concentrate efforts where NIS can be linked with a specific pathway. The Marine Strategy Framework Directive (European Commission 2008, 2010) aimed to achieve or maintain Good Environmental Status (GES) in the marine environment by the year 2020 using a set of environmental targets and associated indicators, 
including biodiversity, the number of newly introduced NIS, abundance and spatial distribution of established NIS, and spatial extent adversely altered habitat (European Commission 2017b). However, impacts for the vast majority of marine NIS remain unknown and have not been quantitatively or experimentally studied over large temporal and spatial scales (Ruiz et al. 2011), and their connections with other drivers of change affecting the marine environment are largely unknown (Stachowicz et al. 2002; Rahel and Olden 2008) to satisfy the criteria for 'adversely altered habitat'. This is far more so for deep-sea ecosystems. Unless impacts are conspicuous, induce direct economic cost, or impinge on human welfare, they fail to arouse public awareness or scientific analysis. It is unlikely that bioinvasion impacts on mesophotic habitats and biodiversity could be discerned unless targeted monitoring and quantification of the presence and abundance of NIS takes place in the most vulnerable areas. The latest assessment of the Member States' monitoring programmes under the MSFD reveals that only $5 \%$ of the programmes are related to NIS, and these "will require a clear acceleration to ensure proper coverage given the MSFD Deadlines for the update of marine strategies by 2018, and achieving Good Environmental Status by 2020" (European Commission 2017a). Crucially, none of the NIS monitoring programmes targeted lower shelf and upper slope habitats, though deep sea communities are in urgent need of conservation (Danovaro et al. 2017a; Guidetti and Danovaro 2018).

Targeted pilot surveys of sensitive, spatially confined slope habitats (e.g. mesophotic 'animal forests', cold seeps) within zones noted for populations of deep-living NIS, will support the need expressed in Commission Decision 2017/848 and will provide new elements to integrate monitoring for descriptors "except where sampling needs to focus on main vectors and risk areas for new introductions." These pilot surveys may serve as a step towards monitoring deep dwelling bioinvasions and their harm to sensitive slope habitats and help establish appropriate protocols to support baselines, targets, and their spatial variability in defining GES for Descriptor 2 in mesophotic habitats.

Acknowledgements We are deeply grateful for the useful comments and suggestions of two anonymous reviewers. The authors acknowledge the support of the DG-ENV project IDEM: Implementation of the MSFD to the Deep Mediterranean Sea (contract EU No 11.0661/2017/750680/SUB/EN V.C2).

Open Access This article is distributed under the terms of the Creative Commons Attribution 4.0 International License (http:// creativecommons.org/licenses/by/4.0/), which permits unrestricted use, distribution, and reproduction in any medium, provided you give appropriate credit to the original author(s) and the source, provide a link to the Creative Commons license, and indicate if changes were made.

\section{References}

Abdelsalam KM (2014) Faunistic study of benthic Pennatulacea (Cnidaria, Octocorallia) from the Northern coast of Egypt. Egypt J Aquat Res 40(3):261-268

Aguilar R, Perry AL, López J (2017) Conservation and management of vulnerable marine benthic ecosystems. In: Rossi S, Bramanti L, Gori A, Orejas C (eds) Marine animal forests-the ecology of benthic biodiversity hotspots. Springer, Switzerland

Akamca E, Mavruk S, Ozyurt CE, Kiyaga VB (2011) First record of the Indo-Pacific burrowing goby Trypauchen vagina (Bloch and Schneider, 1801) in the North-Eastern Mediterranean Sea. Aquat Invasions 6(Suppl. 1):S19-S21

Akel EHKh (2009) Fisheries of experimental purse seine net using light and population dynamics of Sardinella aurita (Family Clupeidae) east of Alexandria, Egypt. Egypt J Aquat Biol Fish 13(1):55-77

Akyol O, Ulas A (2016) The second record of lessepsian migrant Etrumeus golanii from the north-eastern Aegean Sea (Izmir Bay, Turkey). Ann Ser Hist Nat 26(1):25-28

Al Azhar M, Temimi M, Zhao J, Ghedira H (2016) Modeling of circulation in the Arabian Gulf and the Sea of Oman: skill assessment and seasonal thermohaline structure. J Geophys Res Oceans 121:1700-1720

Alavi-Yeganeh MS, Deyrestani A, Murdy EO (2015) First record of the burrowing goby, Trypauchen vagina (Actinopterygii: Gobiidae), from the Iranian coast of the Persian Gulf. Turk J Zool 39:717-720

Boussellaa W, Boudaya L, Derbel H, Neifar L (2016) A new record of the Lessepsian fish Etrumeus golanii (Teleostei: Clupeidae) in the Gulf of Gabes, Tunisia, with notes on its parasites. Cah Biol Mar 57:389-395

Cerrano C, Danovaro R, Gambi C, Pusceddu A, Riva A, Schiaparelli S (2010) Gold coral (Savalia savaglia) and gorgonian forests enhance benthic biodiversity and ecosystem functioning in the mesophotic zone. Biodivers Conserv 19:153-167

Chintiroglou H, Dounas C, Koukouras A (1989) The presence of Corallium rubrum (Linnaeus, 1758) in the eastern Mediterranean Sea. Mitt Zool Mus Berl 65(1):145-149

Çiçek E, Bilecenoglu M (2009) A new alien fish inthe Mediterranean Sea: Champsodon nudivittis (Actinopterygii: Perciformes: Champsodontidae). Acta Ichthyol Pisc 39:67-69 
Coll M, Piroddi C, Steenbeek J, Kaschner K, Ben Rais Lasram F, Aguzzi J, Ballesteros E, Bianchi CN, Corbera J, Dailianis T, Danovaro R, Estrada M, Froglia C, Galil BS, Gasol JM, Gertwagen R, Gil J, Guilhaumon F, Kesner-Reyes K, Kitsos MS, Koukouras A, Lampadariou N, Laxamana E, López-Fé de la Cuadra CM, Lotze HK, Martin D, Mouillot D, Oro D, Raicevich S, Rius-Barile J, Saiz-Salinas JI, San Vicente C, Somot S, Templado J, Turon X, Vafidis D, Villanueva R, Voultsiadou E (2010) The biodiversity of the Mediterranean Sea: estimates, patterns, and threats. PLoS ONE 5(8):e11842

Corsini M, Margies P, Kondilatos G, Economidis PS (2005) Lessepsian migration in Aegean Sea: Tylerius spinosissimus (Pisces, Tetraodontidae) new for the Mediterranean, and six more fish records from Rhodes. Cybium 29(4):347-354

Danovaro R, Aguzzi J, Fanelli E, Billett D, Gjerde K, Jamieson AA, Ramirez-Llodra E, Smith CR, Snelgrove PVR, Thomsen LR, Van Dover CL (2017a) An ecosystem-based deep-ocean strategy. Science 355:452-454

Danovaro R, Corinaldesi C, Dell'Anno A, Snelgrove PVR (2017b) The deep-sea under global change. Curr Biol 27(11):R461-R465

Di Battista J, Randall J, Bowen B (2012) Review of the round herrings of the genus Etrumeus (Clupeidae: Dussumieriinae) of Africa, with descriptions of two new species. Cybium 36(3):447-460

Dinh QM (2018) Aspects of reproductive biology of the red goby Trypauchen vagina (Gobiidae) from the Mekong Delta. J Appl Ichthyol 34:103-110

Erguden D, Turan C (2011) Occurrence of the nakedband gaper, Champsodon nudivittis (Ogilby, 1895) (Osteichthyes: Champsodontidae), in Finike Bay, eastern Mediterranean, Turkey. J Appl Ichthyol 27:1397-1398

European Commission (2008) Directive 2008/56/EC of the European Parliament and the Council of 17 June 2008 establishing a framework for community action in the field of marine environmental policy (Marine Strategy Framework Directive). OJEU 164:19-40

European Commission (2010) Decision on criteria and methodological standards on good environmental status of marine waters. Decision 2010/477/EU. OJEU 232:14-24

European Commission (2017a) Report from the Commission to the European Parliament and the Council assessing member states' monitoring programmes under the Marine Strategy Framework Directive, European Commission, Brussels, 2017

European Commission (2017b) Commission Decision (EU) 2017/848 of 17 May 2017 laying down criteria and methodological standards on good environmental status of marine waters and specifications and standardised methods for monitoring and assessment, and repealing Decision 2010/477/EU. OJEU L 125/43

European Environment Agency (EEA) (2015) State of Europe's seas, technical report no. 2/2015. European Environment Agency, Copenhagen. http://www.eea.europa.eu/ publications/state-of-europes-seas

Falautano M, Castriota L, Andaloro F (2006) First record of Etrumeus teres (Clupeidae) in the Central Mediterranean sea. Cybium 30:287-288
Filiz H, Akcinar SC, Irmak E (2014) Occurrence, length-weight and length-length relationships of Champsodon nudivittis (Ogilby, 1895) in the Aegean Sea. J Appl Ichthyol 30:415-417

Galil BS (2007a) Loss or gain? Invasive aliens and biodiversity in the Mediterranean Sea. Mar Poll Bull 55(7-9):314-322

Galil BS (2007b) Seeing red: alien species along the Mediterranean coast of Israel. Aquat Invasions 2(4):281-312

Galil BS (2008) Alien species in the Mediterranean Seawhich, when, where, why? Hydrobiologia 606(1):105-116

Galil BS (2017) Eyes wide shut: managing bio-invasions in the Mediterranean marine protected areas. In: Goriup PD (ed) Management of marine protected areas: a network perspective. Wiley, New York, pp 187-206

Galil BS, Lewinsohn Ch (1981) Macrobenthic communities of the Eastern Mediterranean continental shelf. Mar Ecol 2(4):343-352

Galil BS, Marchini A, Occhipinti-Ambrogi A (2018) East is east and west is west? Management of marine bioinvasions in the Mediterranean Sea. Estuar Coast Mar Sci 201:7-16

Gökoğlu M, Ünlüsayin M, Balci BA, Özvarol Y, Çolak H (2011) Two alien fish in the Gulf of Antalya: Apogon queketti Gilchrist, 1903 (Apogonidae) and Champsodon nudivittis (Ogilby, 1895) (Champsodontidae). Zool Middle East 54:138-140

Golani D (2000) The Lessepsian migrant, the Red-eye round herring Etrumeus teres (DeKay, 1842), a new record from Cyprus. Zool Middle East 20:61-64

Goren M, Stern N, Galil BS, Diamant A (2011) On the occurrence of the Indo-Pacific Champsodon nudivittis (Ogilby, 1985) (Perciformes, Champsodontidae) from the Mediterranean coast of Israel, and the presence of the species in the Red Sea. Aqua Invasions 6:115-117

Goren M, Ganga U, Jinesh TP (2014) Champsodon vorax and Champsodon nudivittis, two new records from the northeastern Arabian Sea (Perciformes, Champsodontidae). Mar Biodivers Rec 7:e45

Goren M, Galil BS, Diamant A, Stern N, Levitt-Barmats Y (2016) Invading up the food web? Invasive fish in the southeastern Mediterranean Sea. Mar Biol 163:180-191

Gucel MU, Sakalli A (2018) Analysing sea surface temperature change in Gulf of Iskenderun from 1982 to 2015. Nat Eng Sci 3(2):159-168

Guidetti P, Danovaro R (2018) Global ocean conservation under the magnifying glass. Aquat Conserv Mar Freshw Ecosyst 28:259-260

Herut B, Rahav E (2017) The national monitoring program of Israel's Mediterranean waters-scientific report for 2015. Israel Oceanographic and Limnological Research, IOLR Report H48a/2017, Part I. 50 pp [Hebrew]

Hutchins LW (1947) The bases for temperature zonation in geographical distribution. Ecol Monogr 17:325-335

Jimenez C, Achilleos K, Abu Alhaija T, Gili JM, Orejas C (2016) Living in close quarters: epibionts on Dendrophyllia ramea deep-water corals (Cyprus and Menorca channel). Rapp Comm Int Mer Médit 41:466

Kallianiotis A, Lekkas V (2005) First documented report on the lessepsian migrant Etrumeus teres De Kay, 1842 (Pisces: Clupeidae) in the Greek Seas. J Biol Res 4:225-229

Kalogirou S, Corsini-Foka M (2012) First record of the IndoPacific Champsodon nudivittis (Ogilby, 1895) 
(Perciformes, Champsodontidae) in the Aegean waters (eastern Mediterranean Sea). BioInvasions Rec 1:229-233

Kasapidis P, Peristeraki P, Tserpes G, Magoulas A (2007) A new record of the lessepsian invasive fish Etrumeus teres (osteichthyes: Clupeidae) in the Mediterranean sea (Aegean, Greece). Aquat Invasions 2:152-154

Manca B, Burca M, Giorgetti A, Coatannoan C, Garcia M-J, Iona A (2004) Physical and biochemical averaged vertical profiles in the Mediterranean regions: an important tool to trace the climatology of water masses and to validate incoming data from operational oceanography. J Mar Syst 48(1-4):83-116

Micheli F, Halpern BS, Walbridge S, Ciriaco S, Ferretti F, Fraschetti S, Lewison R, Nykjaer L, Rosenberg AA (2013) Cumulative human impacts on Mediterranean and Black Sea marine ecosystems: assessing current pressures and opportunities. PLoS ONE 8(12):e79889

Monahan WB (2009) A mechanistic niche model for measuring species' distributional responses to seasonal temperature gradients. PLoS ONE 4(11):e7921

Murdy EO (2006) A revision of the gobiid fish genus Trypauchen (Gobiidae: Amblyopinae). Zootaxa 1343:55-68

Nemeth D (1994) Systematics and distribution of fishes of the family Champsodontidae (Teleostei: Perciformes), with descriptions of three new species. Copeia 1994(2):347-371

OCEANA (2016) http://eu.oceana.org/en/our-work/ expeditions/deep-sea-lebanon-2016/overview. Accessed 24 Feb 2018

Orejas C, Gori A, Jiménez C, Rivera J, Lo Iacono C, Hadjioannou L, Andreou V, Petrou A (2017) First in situ documentation of a population of the coral Dendrophyllia ramea off Cyprus (Levantine Sea) and evidence of human impacts. Galaxea 19:15-16

Osman AGM, Akel ESH, Farrag MMS, Moustafa MA (2011) Reproductive biology of round herring Etrumeus teres (Dekay, 1842) from the Egyptian Mediterranean water at Alexandria. ISRN, Zoology 215950

Ozer T, Gertman I, Kress N, Silverman J, Herut B (2017) Interannual thermohaline (1979-2014) and nutrient (2002-2014) dynamics in the Levantine surface and intermediate water masses, SE Mediterranean Sea. Glob Planet Change 151:60-67

Pusceddu A, Bianchelli S, Martín J, Puig P, Palanques A, Masqué P, Danovaro R (2014) Chronic and intensive bottom trawling impairs deep-sea biodiversity and ecosystem functioning. Proc Natl Acad Sci USA 111(24):8861-8866

Rahel FJ, Olden JD (2008) Assessing the effects of climate change on aquatic invasive species. Conserv Biol 22:521-533

Ruiz GM, Fofonoff PW, Steves B, Foss SF, Shiba SN (2011) Marine invasion history and vector analysis of California: a hotspot for western North America. Divers Distrib 17:362-373

Salameh P, Sonin O, Golani D (2010) First record of the burrowing goby, Trypauchen vagina (Actinopterygii: Gobiidae: Amblyopinae), in the Mediterranean. Acta Ichthyol Pisc 40(2):109-111

Shaked Y, Genin A (2017) Israel national monitoring program at the Gulf of Eilat. Scientific Report 2016. [Hebrew]

Shankar D, Shenoi SSC, Nayak RK, Vinayachandran PN, Nampoothiri GS, Almeida AM, Michael GS, Ramesh
Kumar MR, Sundar D, Sreejith OP (2005) Hydrography of the eastern Arabian Sea during summer monsoon 2002. J Earth Syst Sci 114(5):459-474

Siokou I, Ateş AS, Ayas D, Ben Souissi J, Chatterjee T, Dimiza D, Durgham H, Dogrammatzi K, Erguden D, Gerakaris V, Grego M, Issaris Y, Kadis K, Katağan T, Kapiris K, Triantaphyllou M, Tsiamis K, Turan C, Tziortzis I, D'udekem D'acoz C, Yaglioglu D, Zaouali J, Zenetos A (2013) New Mediterranean marine biodiversity records. Mediterr Mar Sci 14(1):238-249

Stachowicz J, Terwin RJ, Whitlatch RB, Osman RW (2002) Linking climate change and biological invasions: ocean warming facilitates nonindigenous species invasions. PNAS 99:15497-15500

Stamouli C, Akel EHKh, Azzurro E, Bakiu R, Bas AA, Bitar G, Boyaci YO, Cakalli M, Corsini-Foka M, Crocetta F, Dragičević B, Dulčić J, Durucan F, El Zrelli R, Erguden D, Filiz H, Giardina F, Giovo I, Gonulal O, Hemida F, Kassar A, Kondylatos G, Macali A, Mancini E, Ovali P, Paladini de Mendoza F, Pavičić M, Rabaoui L, Rizkalla SI, Tiralongo F, Turan C, Vrdoljak D, Yapici S, Zenetos A (2017) New Mediterranean biodiversity records (December 2017). Mediterr Mar Sci 18(3):534-556

Tom M, Galil BS (1991) The faunal associations of Haifa Bay, Mediterranean coast of Israel. Mar Ecol 12(1):75-86

Torcu Koç H, Erdogan Z, Sarigöl C (2015) Northward range extension of the nakedband gaper, Champsodon nudivittis (Ogilby, 1895) (Osteichthyes: Champsodontidae), towards Maden Island, Edremit Bay, Turkey. J Appl Ichthyol 31(4):759-761

Vafidis D (2009) First record of Leptogorgia sarmentosa (Octocorallia: Gorgoniidae) from the eastern Mediterranean Sea. Mar Biodivers Rec 2:e17

Vafidis D, Koukouras A (1998) [2002]. Antipatharia, Ceriantharia and Zoantharia (Hexacorallia, Anthozoa) of the Aegean Sea with a checklist of the Mediterranean and Black Sea species. Ann Inst Océanogr, Paris 74(2):115-126

Vafidis D, Koukouras A, Voultsiadou-Koukoura E (1994) Octocoral fauna of the Aegean Sea with a check list of the Mediterranean species: new information, faunal comparisons. Ann Inst Océanogr Paris 70(2):217-229

Vafidis D, Koukouras A, Voultsiadou-Koukoura E (1997) Actiniaria, Corallimorpharia, and Scleractinia (Hexacorallia, Anthozoa) of the Aegean Sea, with a checklist of the eastern Mediterranean and Black Sea species. Isr J Zool 43(1):55-70

Yarmaz A, Balaban C, Türkakin M, Türker-Çakir D (2010) a new record of the lessepsian migrant Etrumeus teres (DeKay, 1842)(osteichthyes: Clupeidae) from the northern aegean sea. J Appl Ichthyol 26:134-136

Zeppilli D, Pusceddu A, Trincardi F, Danovaro R (2016) Seafloor heterogeneity influences the biodiversity-ecosystem functioning relationships in the deep sea. Sci Rep 6:26352

Zibrowius H (1979a) A propos du corail rouge en Méditerranée orientale. Rapp Comm Int Mer Médit 25/26(4):121-122

Zibrowius H (1979b) Campagne de la Calypso en Méditerranée nord-orientale (1955, 1956, 1960, 1964 (suite). 7. Scleractiniaires. Ann Inst Océanogr Paris 55(Suppl):7-28 